\title{
Permainan tradisional engrang dari Provinsi Banten dan pembentukan karakter menghargai prestasi peserta didik MI/SD di Indonesia
}

\author{
Ananda Bella Pratiwi ${ }^{1}$, Anis Fuadah $Z^{2}$ \\ UIN Syarif Hidayatullah Jakarta, Indonesia
}

\begin{abstract}
ABSTRAK
Permainan tradisional dari provinsi Banten dan pembentukan karakter menghargai prestasi peserta didik MI/SD di Indonesia serta memberikan sedikit gambaran mengenai manfaat permainan tradisonal khususnya engrang dalam pembentukan karakter menghargai prestasi peserta didik MI/SD. Topik ini dilatarbelakangi oleh peristiwa dimana peserta didik lebih tertarik pada permainan modern berbasis teknologi canggih seperti game online, akibatnya banyak permainan tradisional yang mulai dilupakan oleh anak-anak bahkan terkesan asing untuk didengar. Selain itu juga permainan modern dapat menimbulkan efek kecanduan sehingga berpengaruh pada perilaku dan karakter peserta didik. Padahal diusia SD/MI adalah waktu yang tepat untuk anak dalam membentuk karakter mereka. Untuk itu, melalui permainan tradisional diharapkan dapat menjadi upaya dalam membentuk karakter peserta didik. Jurnal ini ditulis berdasar pada studi pustaka untuk menjelaskan bahwa permainan tradisional tidak hanya dapat mendorong peseta didik dalam berinteraksi social sesame teman tetapi sesuai dengan judul diatas bahwa karakter peserta didik dalam mengahargai prestasi juga dapat dibentuk melalui permainan tradisional. Untuk itu, permainan tradisional memiliki peran penting pembentukan karakter peserta didik seperti menghargai budaya Indonesia, sebab perilaku tersebut sudah menjadi prestasi bagi peserta didik dalam melestarikan kebudayaan Indonesia.
\end{abstract}

Kata-kata kunci : Permainan tradisional; engrang; karakter; prestasi; peserta didik MI/SD

\section{Engrang traditional game from Banten Province and character formation appreciates the achievements of MI / SD students in Indonesia}

\begin{abstract}
The traditional play from banten province and the formation of achievements of Indonesian elementary school participants, especially with regard to the improvement of the effectiveness of pedagogical participants/ elementary school games. The subject makes learners more interested in high-tech-based modern games such as online games, and consequently, many traditional games that children want to forget are even feel strange for them. Also, modern games have an addictive effect. So it can affect the behavior and personality of the participants. In fact, in ages like elementary school/MI, it is the right time for children to form their characters. Therefore, it is expected to be an effort to build a participant's personality through traditional games. The journal is based on the beading that traditional games can not only can build relationships with friends, but also respect the value of achievement in traditional play according to participants' texts. In this way, traditional games played an important role in the character formation of educational participants, such as respecting Indonesian culture
\end{abstract}

Keywords: traditional game; engrang; character; achievement; elementary school students.

\section{PENDAHULUAN}

Pesatnya perkembangan IPTEK menyebabkan perubahan perilaku serta kebiasaan pada manusia di era globalisasi ini. Di zaman ini segala sesuatunya sudah bergantuk pada teknologi yang canggih. Seperti halnya untuk mendapatkan sesuatu, kita tidak harus pergi ke tempat tersebut, hanya dengan online saja kita bisa memiliki barang yang kita inginkan tanpa harus pergi jauh. Sangat berbanding terbalik dengan 
zaman dahulu, dimana manusia harus memiliki usaha dan membutuhkan upaya yang keras untuk mendapat sesuatu yang kita ingin.

Sebenarnya bukan hanya kehidupan orang dewasa saja yang berubah seiring berjalannya waktu tetapi tanpa kita sadari, teknologi canggih di era ini sudah mampu merubah tingkah laku serta kebiasaan dalam kehidupan anak-anak. Di era modern sekarang ini, banyak anak pada umumnya cenderung tertarik pada permainan yang menggunakan alat-alat canggih dibandingkan permainan tradisional yang terbuat dari bahan alam. Bahkan anak-anak sudah tidak mengenal permainan zaman dulu yang biasa dimainkan oleh orang tua mereka. Anak-anak zaman sekarang lebih menggemari permainan digital berbasis teknologi canggih seperti playstation, game online, ataupun video game. Terlalu sering anak-anak bermain permainan canggih menyebabkan mereka menjadi kecanduan untuk terus bermain game sehingga mengabaikan bahkan terkesan acuh pada kehidupan nyata di sekitarnya .

Menurut mereka, permainan digital terlihat keren karena menggunakan teknologi canggih sehingga anak-anak terkesan hebat jika bisa memainkannya. Sangatlah jauh perbedaannya jika dibandingkan dengan permainan tradisional. Karena pada dasarnya permainan tradisional hanya menggunakan bahan alam seperti bambu, karet, kayu, atau bisa pula batang-batang tumbuhan untuk dijadikan permainan. Bahkan cara memainkannya pun sangat sederhana. Alat yang dimainkan, cara memainkan, serta tempat memainkannya mejadikan permainan zaman sekarang terkesan canggih dan modern. Dalam pemikiran anak-anak, permainan modern adalah permainan yang dimainkan anak kota sedangkan permainan tradisional hanya dimainkan oleh anak kampung serta cara memainkannya sudah ketinggalan zaman. Karena biasanya permainan tradisional lebih menguras energy saat memainkannya apalagi biasanya permainan tersebut di mainkan di luar rumah.

Permainan modern dirasa cukup memberikan kenyamanan dan kemudahan bagi anak-anak sehingga anak-anak lebih memeilih permainan canggih ini. Selain itu juga, banyak orang tua yang mendukung anaknya untuk bermain permainan modern disbanding permainan tradisional. Menurut para orang tua, anak-anak akan lebih sering berada di rumah serta masih dapat dipantau keberadaannya saat bermain di rumah, lain halnya dengan permainan tradisional yang mengharuskan mereka bermain di luar rumah. Para orang tua khawatir jika anak mereka lebih sering bermain di luar rumah. Padahal sebenarnya permainan tradisional adalah salah satu cara utnuk mendorong anak agar lebih mampu melakukan pertemanan, berinteraksi dan bersosialisasi dengan baik (Wafiq Nurul Huda, 2018).

Permainan tradisional dapat menstimulasi peserta didik dalam meningkatkan rasa kepercayaan diri serta kerjasama antar teman. Selain itu, peserta didik mampu menyesuaikan diri dengan lingkungan mereka sehingga mampu berkomunikasi secara positif dan mampu mengontrol emosi diri sendiri, menumbuhkan rasa empati serta mampu menghargai orang lain. Dengan begitu, dapat disimpulkan 
bahwa permainan tradisional dapat memberikan pengaruh yang sangat positif terhadap sikap dan perilaku peserta didik dalam membentuk karakter yang baik dan dapat meningkatkan keterampilan social pada anak.

Permainan tradisional memiliki jenis permainan yang beragam, hal tersebut menjadi daya tarik bagi anak khususnya peserta didik MI/SD. Mengapa demikian? Karena pada umumnya anak-anak mudah bosan jika hanya bermain satu permainan saja. Namun, jika mereka memainkan permainan tradisional mereka tidak akan merasa bosan karena dapat menggantinya dengan permainan lain. Permainan tradisional mempunyai banyak jenisnya, seperti : patok lele, lempar sandal, lompat tali, petak umpet, layang-layang, kelereng, kasti, engklek, congklak, benteng, egrang, pletokan, bekel, gasing, main bola, monopoli, gobak sodor, memanjat pohon, ABC lima dasar, sepeda, masak-masakan dan masih banyak jenis permainan tradisional. Di Indonesia sendiri, setiap daerahnya memiliki permainan tradisional khasnya, namun sudah banyak permainan yang terlupakan sehingga tidak dimainkan lagi (Sibarani, Dina F, 2018).

Permainan tradisional merupakan suatu aktivitas permainan yang tumbuh dan berkembang di daerah tertentu, yang identic akan nilai-nilai budaya dan tata nilai masyarakat yang diajarkan secara turuntemurun dari generasi ke generasi. Dari permainan tersebut, peserta didik mampu meningkatkan bakat dan potensi yang dimiliki. Permainan tradisional, secara hakikatnya memberi rasa bahagia dan puas kepada siapapun yang memainkannya tak terkecuali peserta didik MI/SD. Permainan ini bersifat universal dan umum sehingga permainan tersebut tidak hanya muncul di satu daerah melainkan di daerah lain pula. Hal ini membuktikan bahwa bukan hanya daerah tersebut yang dapat memainkannya tetapi setiap permainan tradisional dapat juga dimainkan oleh anak-anak di daerah lain. Karena pada umunya pula, setiap daerah memiliki cara yang unik dan khas dalam memainkannya (Euis Kurniati, 2016).

Zaman dulu kala, permainan tradisional sangat diminati oleh masyarakat termasuk anak-anak. Karena permainan tersebut bukan hanya sekedar permainan yang dimainkan, tetapi juga memiliki nilai budaya yang terkandung di dalamnya. Tetapi zaman sudah semakin berkembang, banyak budaya luar yang masuk ke budaya sendiri yang tanpa sadar bahwa kita sudah mengalami krisis budaya sendiri. Dengan masuknya budaya luar yang mempengaruhi masyarakat sehingga hal ini mampu menggeser eksistensi budaya di mata masyarakat local sehingga semakin kurangnya minat masyarakat akan kebudayaan daerah mereka dan berpengaruh pada pelestarian permainan tradisional di daerah masing-masing.

Engrang adalah permainan tradisional yang sudah tidak asing didengar dan cukup terkenal di pelosok Nusantara tak terkecuali wilayah Banten. Engrang merupakan salah satu permainan yang terkenal dan cukup sering dimainkan oleh masyrakat Banten. Dalam memainkan permainan ini, dibutuhkan keseimbangan tubuh serta keterampilan saat menaikinya. Egrang terbuat dari 2 batang bambu atau kayu 
dengan panjang kurang lebih 2,5 meter. Pemain berdiri diatasnya untuk menjaga keseimbangan agar tidak jatuh. Pemain yang bisa sampai ke garis finish pertama kali tanpa jatuh, akan menjadi pemenang (Murtafiatun, 2018).

Engrang merupakan permainan masyarakat Banten yang sampai saat ini masih dipermainkan oleh anak-anak. Permainan ini tidak hanya dilakukan oleh pemuda-pemudi saja, tetapi anak-anak dari Bantenpun ikut bermain engrang. Permainan ini biasanya dimainkan di lahan kosong atau lapangan yang luas dan dimainkan oleh banyak anak-anak, biasanya permainan engrang ini dijadikan masyarakat sebagai perlombaan dalam memperingati hari-hari besar tertentu seperti hari kemerdekaan atau hari besar lainnya. Aturan mainnya yaitu siapa yang mencapai garis finish pertama kali tanpa terjatuh dialah pemenangnya, atau juga biasanya pemuda-pemudinya memainkannya dengan cara siapa yang dapat menjatuhkan lawan terlebih dahulu maka dia yang memenangkan permainannya (Afrinel Okwita, Siska Permata Sari, 2019).

Berdasarkan penjelasan diatas, memperkenalkan dan memainkan permainan tradisional merupakan suatu upaya untuk menyadarkan pihak-pihak yang terlibat khsusunya orang tua terkait dampak buruk permainan online. Selain itu, hal tersebut dapat dijadikan sebagapi upaya pelestarian permainan tradisional karena upaya tersebut sangat penting untuk diterapkan mengingat sudah semakin memudar eksistensi permainan tradisional di kalangan anak-anak. Dapat dipahami pula bahwa Indonesia merupakan salag satu negara dengan tingkat kecanduan game online yang sangat tinggi. Dampak yang ditimbulkan pun tidak main-main, karena hal ini sangat berpengaruh terhadap prestasi peserta didik. Tidak hanya itu saja, peserta didik dapat mengalami perubahan sikap atau karakter serta menimbulkan kebiasaan yang buruk, seperti mencuri, melakukan kekerasan, dan tindak criminal lainnya. Berikut ini adalah nilai-nilai penting bermain bagi anak-anak:

1. Sebagai wadah dalam mengekspersikan emosi

2. Meningkatkan keterampilan social

3. Melatih perkembangan verbal serta kemampian Bahasa

4. Mengembangkan kemampuan anak dalam problem solving

Permainan tradisional mungkin memiliki banyak perbedaan dengan permainan modern. Arti dari permainan tradisional mampu mempengaruhi karakter anak anak-anak Indonesia, bukan hanya dari kesan yang didapat saja. Oleh sebab itu dalam memilih permainan harus dilihat dari dampak yang ditimbulkan apakah permainan modern yang justru berdampak buruk tapi terlihat keren atau atau permainan tradisional yang tampak kuno dan sederhana tetapi mampu memberikan dampat posited dalam membentuk karakter para penerus bangsa (Nur, 2013).

Dari berbagai teori yang dipelajari, bahwa pada hakikatnya masa anak-anak adalah masa yang indentik dengan bermain dan melakukan suatu permainan. Oleh sebab itu, permainan merupakan suatu 
kegiatan yang terikat dengan peraturan sehingga tujuan permainan dapat tercapai. Rogers and Sawyers mengemukakan pendapat mereka bahwa bermain merupakan sesuatu yang sangat penting bagi anak di masa sekolah. Menurut KTSP 2007, peserta didik pada usia Sekolah Dasar Tingkat Rendah (kelas 1,2, dan 3) dalam aktivitas belajar mengajar masih memerlukan kegiatan bermain. Karena dalam bermain, fungsi problem solving dapat dikembangkan dalam kehidupan sehari-hari. Nilai dari problem solving itu sendiri maksudnya adalah peserta didik mampu untuk belajar memecahkan masalah (Iswinarti, 2010).

Pada masa kanak-kanak, kita sudah menggunakan seluruh indera untuk menyerap dan menerima pengetahuan, seperti halnya mangkuk lebar yang siap diletakkan apa saja di dalamnya. Banyak tantangan yang dihadapi peserta didik dalam belajar secara efektif dalam satu waktu yang bersamaan. Kitapun tanpa sadar sudah lupa bagaimana mengembalikan dan memanusiawikan kembali bahwa belajar bukanlah melulu soal konsep kognitif atau hal akademik melainkan seluruh tubu, jiwa, raga, dan ekspresi juga dieksplor dan dilibatkan secara utuh dalam satu kesatuan yang saling berkaiitan dan tidak dapat dipisahkan. Ribuan tahun yang lalu telah muncul media pembelajaran yang alamiah yang bersumber dari hubungan alam dan tradisi. Hasil karya cipta manusia merupakan refleksi dari pengimplementasian permainan tradisional yang melibatkan unsur budaya yang tidak akan lepas dari interaksi dengan alam sekitar.

Di era modern yang serba canggih dan penuh akan teknologi, jika kita mendengar kata permainan tradisinonal rasanya seperti mengulang masa kanak-kanak dulu yang dimana kita langsung teringat akan permainan yang biasa kita mainkan bersama teman-teman, jika kita cermati dan telaah lebih dalam semua permainan tradisional dari berbagai wilayah di Indonesia memiliki landasan filosofis berupa nilai-nilai kearifan local yang dijadikan sebagai acuan dalam pandangan hidup dalam berperilaku seperti gotong royong, toleransi, kekeluargaan, rasa cinta tanah air, serta rasa senasib seperjuangan.

Permainan dapat dikategorikan menjadi tiga golongan, yakni pertama, permainan untuk bermain (rekreatif) biasanya dilakukan saat waktu luang. Dalam hal ini, permainan tidak mengenal menang atau kalah, yan terpenting kita berbagi kebahagiaan di waktu yang luang tanpa menjatuhkan lawan bermain. Kedua, permainan tradisional bersifat kompetitif yaitu biasa dimainkan oleh dua pemain atau lebih untuk menentukan pemenangnya. Selain itu permainannya terikat dengan peraturan dan lebih teroganisir. Untuk itu bagi para pemain dibutuhkan keahlian khusus, contohnya dalam bermain engrang, mereka harus menjaga keseimbangan saat menaikinya dan membutuhkan kecepatan agar bisa sampai di garis akhir terlebih dahulu. Dan yang ketiga, permainan tradisional bersifat edukatif yaitu dalam permainan terdapat unsur-unsur pendidikan, baik itu berupa keterampilan ataupun kecakapan yang dikembangkan agar peserta didik mampu mengimplemetasikannya dalam kehidupan sehari-hari. Hal ini dapat dikatakan 
sebagai pendidikan non-formal dalam masyarakat yang dijadikan alat sosialisasi bagi peserta didik dalam meyesuakan diri di dalam kelompok social (Misbach, 2006).

Berbicara tentang permainan tradisional bersifat edukatif dimana menyimpan unsur pendidikan di dalamnya. Dimana banyak sekali yang mampu dikembangkan melalui permainan tradisional ini. Salah satunya ialah karakter. Dalam hal ini sangat diperlukannya pendidikan karakter bagi siswa. Sekolah merupakan sarana social yang memiliki banyak sekali peranan dan fungsi. Salah satunya dengan membimbing, memperkenalkan, serta memahami peserta didik dalam berkehidupan di lingkungan sekitar mereka. Dalam membentuk karakter di sekolah ini bukan hanya sebagai pembelajaran atau pengetahuan tetapi juga melalui penerapan serta pengimplementasian nilai-nilai kehidupan. Ada banyak sekali berbagai macam karakter yang harus dipelajari dan dikembangkan oleh siswa. Salah satunya adalah karakter dalam menghargai prestasi siswa.

Perilaku menghargai prestasi adalah satu dari sekian banyak karakter baik dalam pribadi peserta didik yang harus ditumbuhkembangkan. Karakter ini mengharuskan peserta didik untuk mengembangkan pengetahuan dan keterampilan siswa. Selain itu dapat memotivasi peserta didik agar terdorong kesadarannya untuk belajar dengan rajin, ulet, tekun, serta memiliki jiwa kompetitif untuk selalu berusaha dan meningkatkan kemampuan pengetahuan dan keterampilan agar mampu menyelesaikan berbagai permasalahan yang dihadapi, mampu menerapkan keahlian yang dimiliki di kehidupan masa depannya kelak. Guru diharapkan mampu untuk memberi peluang serta kesematan kepada peserta didik dalam mengembangkan kemampuannya. Seperti contoh, guru memberikan penghargaan atau reward kecil bagi peserta didik yang mampu berada di peringkat atas diantara teman-temannya. Dari hal tersebut munculah dorongan bagi siswa agar mereka senantiasa meningkatkan prestasi mereka dan mengembangkan kemampuan satu sama lain. (Rianawati, 2014)

\section{METODE PENELITIAN}

Adapun dalam penelitian kali ini, metode yang diguanakan adalah studi kepustakaan atau kajian pustaka, yaitu metode yang didalamnya terdapat teori atau materi yang berkesinambungan dengan masalah dalam penelitian. Dalam hal ini, masalah yang terdapat dalam jurnal imiah ini adalah untuk mengetahui "Permainan Tradisional Engrang dari Provinsi Banten dan Pembentukan Karakter Menghargai Prestasi Peserta Didik MI/SD di Indonesia". Pendekatan kepustakaan (library research) atau studi pustaka dapat didefinisakn sebagai kegiatan yang berkaitan dengan metode membaca dan mencatat teori yang didapat dari pengumpulan data pustaka serta mengolah data atau bahan yang sudah diperoleh dalam penelitian. Dalam pengkajian studi pustaka ini, peneliti harus memperhatikan empat ciri utama dalam memakai metode ini, antara lain: Pertama, dikarenakan peneliti tidak berhubungan langsung dengan 
pengetahuan di lapangan maka peneliti harus bersedia untuk berhadapan langsung dengan data berupa teks ataupun deretan angka. Kedua, peneliti terjun langsung pada data studi pustaka, untuk itu data tersebut harus "siap pakai" dan sudah dinyatakan kebenarannya karena peneliti tidak berhadapan dengan studi lapangan. Ketiga, data dari kajian pustaka ini pada dasarnya merupakan data dari orang kedua, maksudnya peneliti tidak langsung mendapat data dari narasumber atau lapangan, melainkan hanya membaca karya narasumber. Dan yang terakhir, data kepustakaan tidaklah dibatasi oleh waktu dan ruang. Dari pembahasan metode diatas, maka dalam mengumpulkan data dalam penelitian dapat dilakukan dengan membaca, menelaah, mengamati, mengeksplorasi berbagai macam dokumen yang valid datanya seperti beberapa jenis jurnal, buku (baik itu buku elektronik maupun buku cetak), serta data informasi yang berhubungan dengan kajian atau masalah dalam penelitian (Supriyadi, 2016).

\section{HASIL DAN PEMBAHASAN}

\section{Permainan Tradisional Engrang}

Menurut penelitian secara empiris membuktikan bahwa kemampuan anak-anak jauh lebih berkembang ketika mereka memainkan permainan tradisional. Dalam hal ini kemampuan berkomunikasi, bekerja sama, sportifitas, membangun strategi, dan kemampuan fisik mereka (berlari, melompat, keseimbangan) serta karakter anak mampu berkembang secara pesat. Dalam hal ini pula dibuktikan bahwa permainan tradisional mampu mempengaruhi kecerdasan anak-anak Indonesia.

Meskipun banyak manfaat yang terjadi di dalam permainan tradisional dalam mempengaruhi tumbuh kembang anak, namun tidak banyak orang tua yang mengetahui hal tersebut. Sangat jarang pula orang tua yang mengingat nama permainan tradisional dan bagaimana cara mempermainkannya. Hal itu menjadikan eksistensi permainan tradisional ini semakin berkurang keberadaan bahkan sangat jarang diketahui oleh masyarakat terutama anak-anak.

Salah satu cara untuk mengenalkan serta melestariakan permainan tradisional ini adalahg dengan melakukan identifikasi terhadap berbagai macam permainan yang mungkin dulu sering dimainkan masyarakat. Upaya ini telah diberlakukan sekitar tahun 1979/1980 dimana terdapat 20 permainan rakyat yang dapat diidentifikasi dan akan dijadikan buku atau tulisan yang akan dipublikasikan lewat media digital. Namun, hal tersebut masih belum diketahui perencanaannya. Dengan upaya tersebut diharapkan akan menjadi dorongan dan dukungan bagi pemerintah Indonesia dalam rangka meningkatkan kesadaran masyarakat akan pentingnya pendidikan nasional yang bebasis kebudayaan. Seperti yang tercantum pada pasal I ayat 2 Undang-undang No. II tahun 1989 yang berisi pengertian tentang penyelenggaraan pendidikan nasional anak tetap berpijak pada bumi dan bergantung pada budaya Indonesia dengan memasukkan nilai kearifan lokal (Nofrans Eka Saputra, 2017) 
1. Sejarah Permainan Engrang

Sejarah permainan engrang belum diketahui secara pasti dan tidak begitu dikenal oleh masyarakatkarena pada umumnya mereka hanya memainkannya tanpa perlu tahu bagaimana permaian ini terbentuk. Permainan engrang adalah salah satu permainan yang mudah ditemukan karena engrang tidak memerlukan bahan yang sulit untuk ditemukan serta tidak harus mengeluarkan biaya yang banyak. Namun, minat generasi muda zaman sekarang terhadap permainan engrang sudah semakin luntur akibat pengaruh modernisasi yang masuk ke Indonesia yang mengakibatkan engrang sudah tidak pernah dimainkan kembali. Modernisasi yaitu sebuah proses perubahan menuju hal-hal lebih modern dan maju disbanding hal-hal tradisional dan kuno yang bertujuan untuk mengembangkan kualitas hidup masyarakat. Karena pengaruh tersebut generasi saat ini lebih memilih permainan modern yang langsung bisa dimainkan tanpa harus membuatnya terlebih dahulu (Afrinel Okwita, Siska Permata Sari, 2019)

Dalam Sastra Jawa, permainan engrang berasal dari kata egrang-egrangan yang mengandung arti dolanan dengan menggunakan alat bernama engrang. Engrang memiliki makna kayu atau bamboo yang dijadikan sebagai pijakan kaki. Permainan ini terbuat dari dua batang bambu karena bamboo memiliki struktur batang lebih kokoh dibanding dengan kayu. Biasanya jenis bamboo yang digunakan adalah wulung atau bamboo apus. Ukuran sepasang bamboo ini sekitar 2 meter atau umumnya melebihi tinggi pemain. Setelah itu terdapat bagian yang dipergunakan untuk pijakan kaki dengan panjang sekitar 20-30 $\mathrm{cm}$. untuk dijadikan sebagai engrang, sekitar $50 \mathrm{~cm}$ dari alas bamboo dilubangi kemudian bagian untuk pijakan kaki dimasukkan kedalam lubanng. Permainan engrang ini tidak memiliki jumlah batasan pemain. Artinya permainan ini mampu dimainkan baik secara individu maupun berkelompok. Biasanya tujuan dari memainkan engrang ini adalah untuk mengisi waktu luang atau sekedar bermain santai dan jarang ditemukan permainan ini digunakan dalam perlombaan (Hikmah, 2011)

Permainan engrang merupakan permainan tradisional yang berasal dari Banten yang sudah dimainkan oleh masyrakat sejak zaman dahulu. Selain dijadikan sebagai permainan, orang-orang terdahulu menjadikan engrang sebagai alas kaki mereka karena dahulu mereka belum mengenal sandal. Engrang biasa dimainkan hanya untuk menambah kesenangan anak-anak tapi ada pula yang memainkannya sebagai pertandingan atau pertunjukkan di suatu daerah. Karena engrang memiliki makna khusus yang yang sudah diturunkan secara turun-menurun dari nenek moyang terdahulu (Malik, 2019).

\section{Tata Cara Bermain Permainan Engrang}

Terdapat dua jenis permainan engrang yang yang cukup dikenal oleh masyarakat yaitu engrang bamboo dan engrang tempurung kelapa.

- Engrang Bambu 
Engrang jenis ini merupakan salah satu jenis engrang yang paling banyak dimainkan oleh masyarakat karena dari proses pembuatannya pun sangat sederhana. Engrang ini dibuat dengan menggunakan bahan dasar dua batang bamboo (masyarakat lebih sering menggunakan bamboo dibandingkan kayu, karena kayu mudah patah dan rusak) yang masing-masing memiliki panjang sekitra 2 meter, yang kemudian $50 \mathrm{~cm}$ dari alas bamboo dilubangi untuk disisipkan bamboo dengan ukuran panjang sekitar $30 \mathrm{~cm}$ yang dijadikan sebagai pijakan kaki.

Berikut ini (Bangsawan, 2019) adalah penjelasan cara bermain engrang bamboo :

1) Sebelum bermain, siapkan engrang terlebih dahulu

2) Menegakkan engrang dan sedikit condongkan engrang ke depan

3) Memposisikan engrang dengan tidak sejajar, dimana salah satu kaki engrang berada di belakang dan satunya berada di belakang

4) Mulai dengan menginjakkan kaki pada salah satu pada pijakan kaki di salah satu engrang, kemudian diikuti dengan kaki satunya dipijakkan pada engrang lain

5) Untuk memastikan bahwa posisi sudah seimbang atau belum, mulai dengan berjalan di tempat dan jangan berhenti

6) Jatuhkan kaki di antara engrang apabila sudah merasa ingin terjatuh

7) Usahakan untuk bermain di tempat luas, seperti lapangan atau halaman.

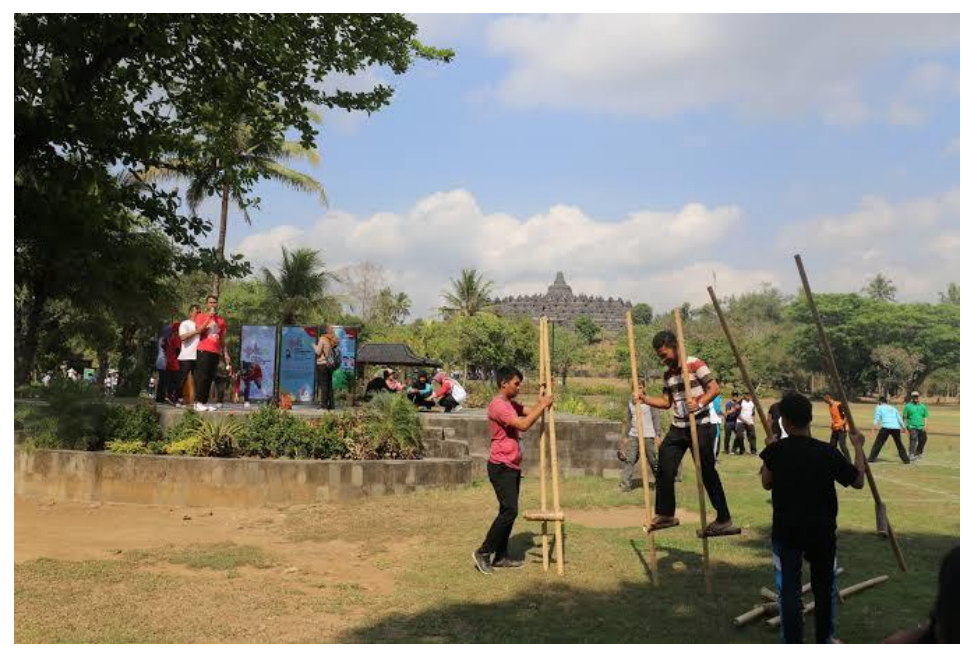

Gambar 1. Ayoo dolanan! (Sumber : kebudayaan.kemdikbud.go.id)

- Engrang Tempurung Kelapa

Engrang jenis ini adalah salah satu jenis permainan tradisional yang mungkin belum diketahui dari mana asal-muasalnya. Namun, engrang ini memiliki nama yang berbeda di setiap daerah. Seperti di Kalimantan Selatan, nama permainan ini adalah Batungkau, lain halnya di Jawa 
Tengah, nama permainan ini adalah Jangkungan. Kata Engrang itu sendiri berasal dari Bahasa Lampung yang artinya terompah tinggi yang terbuat dari bamboo panjang. Berbeda dengan engrang tempurung kelapa, permainan ini terbuat dari dua buah tempurung kelapa yang disatukan dengan tali. Permainan ini dimainkan dengan cara berlomba menggunakan engrang tempurung dimulai dari garis awal sampai garis akhir, pemenang ditentukan dari siapa yang sampai terlebih dahulu dan tidak jatuh selama permainan. Permainan ini dapat dimainkan dimana saja dan tidak memerlukan tempat yang khusus, biasanya dimainkan di lapangan yang cukup luas atau halaman yang berukuran 7-15 meter dengan lebar 3-4 meter (Khusnul Laely, Dede Yudi, 2015).

Berikut ini adalah penjelasan tata cara bermain engrang batok kelapa:

1) Haruslah ada pemain jika ingin memainkan permainan ini

2) Setiap pemain disediakan engrang tempurung yang sudah dikaitkan dengan tali

3) Tentukan garis awal serta garis akhir permainan

4) Apabila pemain lebih dari 10 orang maka dianjurkan dibagi menjadi 2 kelompok

5) Lakukan pengundian untuk melakukan perlombaan

6) Sebelum memulai permainan, para pemain sudah memegang engrang dan berada di belakang garis start

7) Wasit memberi aba-aba "bersedia" maka pemain memegang engrang, aba-aba "siap" maka kedua kaki pemain sudah harus bertumpu diatas tempurung kelapa, aba-aba "ya" artinya pemain sudah harus berjalan menuju garis finish tanpa jatuh dari engrang

8) Apabila pemain jatuh dari engrang atau menginjak garis pembatas maka dinyatakan gugur.

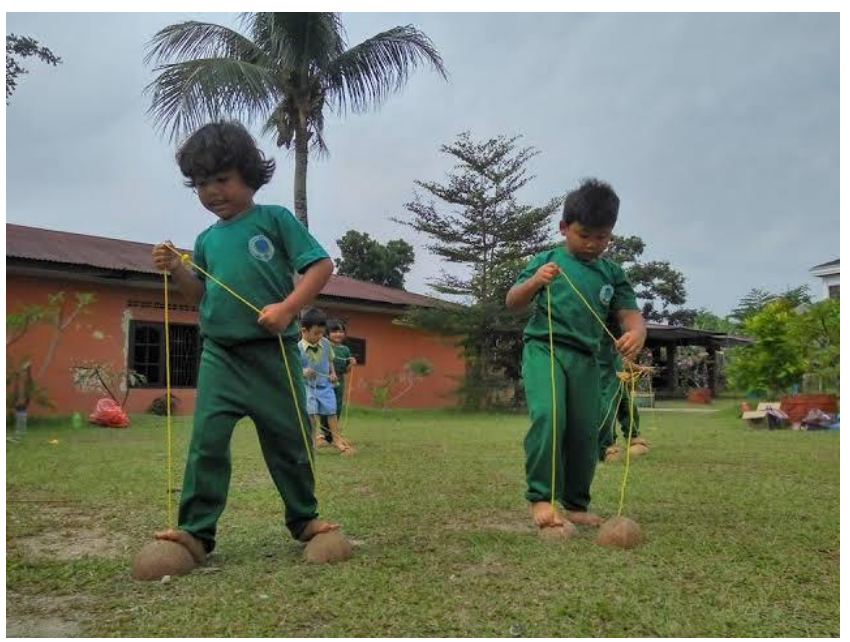

Gambar 2. (sumber : semangat-bangsa.sch.id)

3. Manfaat Permainan Engrang

Permainan engrang merupakan salah satu permainan tradisional yang cukup terkenal di Indonesia. Namun, yang terjadi sekarang adalah keberadaan permainan ini sudah semakin menghilang karena sudah 
sangat jarang ditinggalkan. Karena terbukti kalangan masyarakat khususnya anak-anak sudah tidak mengenal permainan engrang. Padahal permainan tradisional khususnya engrang ini memiliki banyak manfaat yang didapat ketika kita bermain, salah satunya adalah keseimbangan. Selain itu sudah sangat terlihat sekali dampak yang didapat dari permainan engrang yang dapat mempengaruhi perkembangan diri pada anak. Anak dapat mengeluarkan hasrat, kebutuhan, dan tuntutan dari perkembangan psikologi mereka yang meliputi nilai, kognitif, sikap, motoric, social, sikap hidup serta kreativitas pada saat mereka bermain permainan engrang. Dalam hal memperluas kemampuan anak melalui permainan tradisional merupakan upaya yang tepat untuk mengeksplorasi bakat anak sehingga mampu berkembang secara optimal.

Untuk melatih keseimbangan anak dalam bermain permainan engrang adalah dengan cara menjaga keseimbangan saat menaiki dua buah bamboo atau batok, dimana saat anak bermain maka otomatis tubuh mereka akan berusaha menyesuaikan keseimbangan tubuh mereka diatas engrang agar tidak jatuh dan tetap konsisten berdiri tegak saat mereka berjalan agar tidak terjatuh. Dengan begitu otototot serta energy dalam tubuh anak menjadi berkontraksi dan mampu meningkatkan stamina tubuh mereka untuk mengendalikan gerakan tubuh mereka sendiri (A. Faisol Badrus, 2019)

\section{A. Pembentukan Karakter Menghargai Prestasi}

Setiap pendidikan pasti memiliki tujuan dan acuan yang ingin dicapai serta pedoman dalam menjalankan system pendidikan, begitupun dengan pendidikan di Indonesia dimana pacuan pendidikannya berupa kurikulum yang dinamakan kurikulum 2013. Terdapat 3 aspek yang dinilai dalam kurikulum 2013 diantaranya, psikomotorik, afektif, dan kognitif. Namun, dari ketiga aspek tersebut terdapat satu aspek yang saat ini masih banyak diperbincangkan dalam lingkungan pendidikan yaitu aspek afektif. Penilaian afektif ini biasa kita sebut dengan penilaian karakter atau sikap dari peserta didik. Jika kita hubungkan pendidikan karakter ini sama dengan pendikan watak atau nilai dan pendidikan budi pekerti. Maksud dari pendidikan nilai atau moral ini diartikan sebagai adanya hubungan dengan dunia pendidikan dimana peserta didik diwajibkan utnuk mengikuti program pendidikan karakter ini yang bertujuan untuk membentuk karakter dan moral yang positif yang berpedoman pada dasar nilai agama peserta didik.

Dalam hal ini, pemerintah sudah memberi tindakan dan respon positif terkait pendidikan moral tersebut dalam Kebijakan Nasional Pembangunan Karakter Bangsa. Isi dari kebijakan tersebut antara lain tentang arah, tahapan kebijakat serta strategi yang diperlukan dalam pengembangan nilai moral bangsa, terutama peserta. Kemendiknas sudah menentukan delapan karakter atau moral yang wajib tertanam pada diri peserta didik, yaitu sebagai berikut : 
1. Peduli social

2. Tanggung jawab

3. Jujur

4. Toleransi

5. Religious

6. Peduli lingkungan

7. Gemar membaca

8. Cinta damai

9. Disiplin

10. Kreatif

11. Kerja keras

12. Bersahabat/komunikatif

13. Cinta tanah air

14. Menghargai prestasi

15. Rasa ingin tahu

16. Mandiri

17. Demokratif

18. Semangat kebangsaan.

Dari berbagai karakter yang disebutkan terdapat satu karakter yang cukup menarik diperbincangkan, yaitu karakter menghargai prestasi. Sebenarnya karakter ini sudah sangat umum dibicarakan oleh kalangan para pendidik di dunia pendidikan. Mengapa demikian? Karena karakter ini lebih mengutamakan peserta didik untuk mendorong pribadi mereka agar selalu berguna dalam kehidupan bermasyarakat, meningkatkan rasa toleransi terhadap keberadaan orang lain serta mampu menghargai dan mengapresiasi apa yang telah dicapai oleh diri sendiri maupun orang lain (Wenny Sutomo, Vetty Milyani, 2019).

Pengertian karakter menghargai prestasi adalah suatu tindakan ataiu perilaku yang memotivasi pribadi dalam membentuk hal-hal yang bermanfaat bukan hanya untuk diri sendiri tetapi juga bagi keluarga, teman, masyarakat, bangsa dan negara serta dapat menghargai sesuatu yang telah dicapai oleh orang lain. Karakter ini sebenarnya termasuk bagian dari pendidikan agama Islam. Dapat dikatakan dengan adanya karakter menghargai prestasi, kita diwajibkan untuk meningkatkan serta memperdalam berbagai bidang dalam kehidupan demi kebaikan seluruh masyarakat. Dalam surat Al-Baqarah ayat 148 dijelaskan bahwa manusia dituntut berprestasi serta senantiasa memiliki jiwa kompetitif dengan harapan umat manusia saling berlomba-lomba dalam berbuat kebaikan dan mencari pahala. 
“....... Maka berlomba-lombalah kamu dalam kebaikan...”. (QS. Al-Baqarah/2 : 148 )

Selain itu, dalam surat Ar-Ra'du ayat 11 Allah Swt berfiman bahwa ia tidak akan merubah nasib seseorang, jika bukan mereka sendiri yang berusaha untuk merubah nasib hidup sendiri. Dari ayat tersebut dijelaskan bahwa sebagai hamba-Nya, umat manusia haruslah berusaha untuk mencapai prestasi agar kehidupan yang dijalani dapat berjalan dengan baik seiring berjalannya waktu, dan dapat membawa dampak positif bagi diri sendiri maupun orang lain.

“.......Sesungguhnya Allah tidak mengubah keadaan suatu kaum sebelum mereka mengubah keadaan diri mereka sendiri...." (QS. Al-Ra'du/13: 11)

Dari ayat diatas, dapat kita ketahui bahwa karakter menghargai prestasi sangat penting yang berarti ini merupakan suatu upaya pencapaian dan pengembangan kualitas hidup seseorang dalam berbagai bidang kehidupan. Tanpa adanya penghargaan prestasi, siklus hidup keadaan manusia tidak akan ada kemajuan dan peningkatan. Berdasarkan uraian rumusan dari Kemendiknas Balitbang Puskur tahun 2010, terdapat beberapa poin sikap menghargai prestasi, yaitu:

1. Giat belajar untuk mendapat prestasi yang tinggi

2. Mengerjakan dengan sungguh-sungguh tugas yang diberikan guru

3. Tekun dalam berlatih agar berprestasi dalam bidang oalhraga dan seni

4. Menghormati semua hal yang dilakukan dan diatur baik itu oleh guru, kepala sekolah ataupun staff sekolah lain

5. Bercerita kepada orang tua tentang prestasi yang didapat

6. Membentuk hasil dari program kerja pemimpin di kehidupan masyarakat sekitar

7. Menghargai tradisi, kebiasaan, dan hasil karya masyarakat sekitar

8. Menghargai penemuan-penemuan terbaru yang ditemukan manusia baik itu dalam bidang ilmu, social, teknologi, budaya, ataupun seni

9. Berlatih keras agar selalu menjadi pemenang dalam berbagai kegiatan di sekolah

10. Menghargai kerja keras guru, kepala sekolah, dan staff sekolah

11. Menghargai upaya orang tua yang sudah berusaha mengembangkan potensi serta bakat dirinya melalui pendidikan dan kegiatan lainnya

12. Menghargai hasil dari program kerja pemimpin dalam memajukan kesejahteraan rakyat, bangsa, dan negara. (Rianawati, 2014)

Karakter atau nilai menghargai prestasi dapat ditinjau dari penghargaan seseorang terhadap orang lain yang mendapatkan prestasi. Penghargaan yang diberi untuk menunjukkan sikap menghargai prestasi bukan hanya berupa hadiah atau barang, tetapi bisa juga berbentuk pujian atau dukungan dan dorong yang dimaksudkan agar seseorang mampu mempertahankan prestasi yang telah diperoleh. Memuji suatu 
karya atau prestasi adalah bentuk rasa bangga kita kepada seseorang yang berprestasi selain itu juga mampu menjadi kebanggan tersendiri bagi seseorang yang berprestasi tersebut untuk terus bersemangat dalam berkarya dan berprestasi (Rizki Kurniawati, 2018).

\section{SIMPULAN}

Seiring berkembangnya teknologi, permainan tradisonal mungkin sudah jarang sekali untuk dipermainkan karena keberadaannya yang semakin terlupakan. Padahal permainan tradisional menyimpan banyak sekali manfaat dan kegunaan. Kehadiran permainan modern berbasis online yang menggunakan alat elektronik yang canggih membuat eksistensi permainan tradisional semakin menurun. Dibanding dengan permainan modern, sebenarnya permainan tradisional memiliki banyak sekali keunggulan. Salah satunya, dengan memainkan permainan tradisional merupakan suatu upaya untuk melestarikan kebudayaan Indonesia. Salah satu permainan tradisional Indonesia adalah engrang. Permainan yang terbuat dari batok kelapa ataupun bamboo ini berasal dari provinsi Banten yang biasa dimainkan oleh anak-anak maupun orang dewasa. Banyak sekali kegunaan engrang ini, selain untuk permainan, orang terdahulu menggunakan engrang sebagi alas kaki mereka ketika bepergian.

Dari permainan engrang ini, terdapat beberapa karakter yang dapat dikembangkan, salah satunya adalah karakter menghargai prestasi. Menurut beberapa sumber, permainan engrang dinilai dapat meningkatkan karakter menghargai prestasi. Dengan bermain engrang, peserta didik mampu mengembangkan bakat mereka dalam permainan engrang sehingga dapat diikutsertakan dalam perlombaan. Apabila peserta didik mampu memenangkan lomba, secara tidak langsung pengalaman tersebut dapat dijadikan motivasi untuk terus menambah prestasi mereka. Selain itu, dengan bermain engrang peserta didik sudah melakukan upaya untuk melestarikan budaya asli Indonesia. Hal tersebut juga merupakan suatu prestasi karena sudah sangat jarang anak-anak zaman sekarang yang memainkan permainan tradisional. Jadi, bermain permainan engrang merupakan suatu usaha dalam menghargai tradisi, serta kebudayaan dalam bidang kesenian. Sekaligus sarana dalam meningkatkan ketekunan dalam berolahraga karena engrang mampu melatih otot-otok kaki dan tangan dalam meningkatkan keseimbangan tubuh.

\section{DAFTAR PUSTAKA}

A. Faisol Badrus, S. M. (2019). Pengaruh Permainan Tradisional (Egrang Bambu) terhadap Peningkatan Keseimbangan pada Anak Kelas 5 SD. Sport Science and Health, 244.

Afrinel Okwita, Siska Permata Sari. (2019). EKSISTENSI PERMAINAN TRADISIONAL EGRANG PADA MASYARAKAT MONGGAK KECAMATAN GALANG KOTA BATA. Jurnal Program Studi Pendidikan Sejarah, 21. 
Al-Qur'an dan terjemahannya, 2002, Jakarta

Bangsawan, I. P. (2019). Direktori Permainan Tradisional. Banyuasin, Sumatera Selatan: Dinas Pendidikan, Pemuda, Olahraga, dan Pariwisata.

Euis Kurniati. (2016). PERMAINAN TRADISIONAL DAN PERANNYA DALAM MENGEMBANGKAN KETERAMPILAN SOSLAL ANAK. JAKARTA: Prenadamedia Group.

Hikmah, M. (2011). PERANCANGAN GAME TRADISIONAL JAWA EGRANG BAMBU. Skripsi, 4.

Iswinarti. (2010). NILAI-NILAI TERAPIUTIK PERMAINAN TRADISIONLA ENGKLEK PADA ANAK USIA SEKOLAH DASAR. 41 - 42.

Khusnul Laely, Dede Yudi. (2015). PENGARUH PERMAINAN EGRANG TEMPURUNG KELAPA TERHADAP PENINGKATAN KECERDASAN KINESTETIK ANAK · Jurnal EMPOWERMENT, 35-38.

Malik, K. (2019). PERBEDAAN NILAI (VALUE) DAN MAKNA (MEANING) BUDAYA PERMAINAN EGRANG DI EMPAT NEGARA. Jurnal Seni Rupa, 197.

Misbach, I. H. (2006). PERAN PERMAINAN TRADISIONAL YANG BERMUATAN EDUKATIF DALAM MENYUMBANG PEMBENTUKAN KARAKTER DAN IDENTITAS BANGSA. $3,4,13,14,15$.

Murtafiatun. (2018). Kumpulan Permainan Tradisional Nusantara. Yogyakarta: C-Klik Media. .

Nofrans Eka Saputra, Y. N. (2017). PERMAINAN TRADISIONAL SEBAGAI UPAYA MENINGKATKAN KEMAMPUAN DASAR ANAK. Jurnal Psikologi, 49-50.

Nur, H. (2013). MEMBANGUN KARAKTER ANAK MELALUI PERMAINAN ANAK TRADISIONAL. Jurnal Pendidikan Karakter, 90-91.

Rianawati. (2014). Implemetasi Nilai-Nilai Karakter Pada Mata Pelajaran Pendidikan Agama Islam (PAI). Pontianak: IAIN Pontianak Press.

Rizki Kurniawati, I. (2018). ANALISIS NILAI KARAKTER DALAM TEKS CERITA BUKU PELAJARAN SISWA SEKOLAH DASAR. Master Bahasa, 109.

Sibarani, Dina F. (2018). Permainan Tradisional Terhadap Pembentukan Karakter Anak (Studi Etnografi di Desa Sikeben, Kecamatan Sibolangit, Kabupaten Deli Serdang). Skripsi, 1-3.

Supriyadi. (2016). Community of Practitioners : Solusi Alternatif Berbagi Pengetahuan Antar Pustakawan. jurnal pustaka, 85.

Wafiq Nurul Huda. (2018). PEMBENTUKAN KARAKTER PADA SISWA SEKOLAH DASAR MELALUI PERMAINAN TRADISIONAL. 244.

Wenny Sutomo, Vetty Milyani. (2019). Mengidentifikasi Karakter "Menghargai Prestasi” Peserta Didik Kelas VIII SMP N 5 Muaro Jambi. Jurnal Publikasi Pendidika, 111. 